Available online on 15.06.2021 at http://jddtonline.info
Open Access to Pharmaceutical and Medical Research

Open Access Full Text Article

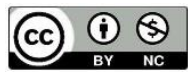

Research Article

\title{
Design, Development and Evaluation of Silk Based Film Forming Spray for Wound Healing
}

\author{
iD Vipul Wayal *, K. Nagasree, B. A. Vishwanath
}

Department of Pharmaceutics, Aditya Bangalore Institute of Pharmacy Education \& Research, Bangalore-560064, Karnataka, India. Affiliated to Rajiv Gandhi University of Health Sciences, Bangalore, Karnataka

\begin{tabular}{|c|c|c|}
\hline \multicolumn{2}{|l|}{ Article Info: } & Abstract \\
\hline $\begin{array}{l}\text { Cite this artic } \\
\text { Wayal } \mathrm{V} \text {, Nagasre } \\
\text { Development anc } \\
\text { Forming Spray fo } \\
\text { Delivery and The } \\
\text { DOI: http://dx.dc }\end{array}$ & $\begin{array}{l}\text { Article History: } \\
\text { Received } 06 \text { April } 2021 \\
\text { Review Completed } 14 \text { May } 2021 \\
\text { Accepted 19 May } 2021 \\
\text { Available online 15 June } 2021\end{array}$ & $\begin{array}{l}\text { The objective of the present study is to formulate and evaluate Silk based film forming } \\
\text { spray for wound healing. On the wound surface the solution solidifies into a film which can } \\
\text { deliver the active moiety on site of action. The spray solution was prepared by simple } \\
\text { mixing of active extract of Centella Asiatica, Silk Protein and various film forming polymers. } \\
\text { Silk protein form scaffold for active fibroblast movement and Asiaticosides from Centella } \\
\text { Asiatica extract improve and fasten collagen synthesis. A clear yellowish solution was } \\
\text { obtained. The formulations (F1-F8) had a pH range between } 5.5-6.5 \text {, which was close to } \\
\text { the pH of skin. The viscosity of formulation in range of } 25-50 \mathrm{cps} \text {, completely dry film } \\
\text { formed within } 5 \text { min in open environment. The Effects of polymers, plasticizers and } \\
\text { solvents on spreadability. Surface tension and Spray angle were studied. The high content } \\
\text { of ethanol in the formulation fastens the drying time. The results indicated that formulation } \\
\text { (F8) showed good spreadability and less drying time. }\end{array}$ \\
\hline
\end{tabular}

Keywords: Film forming spray, Wound healing, Silk protein, Asiaticoside, Scaffold.

\footnotetext{
*Address for Correspondence:
}

Mr. Vipul Wayal, Department of Pharmaceutics, Aditya Bangalore Institute of Pharmacy Education \& Research, Bangalore-560064, Karnataka, India. ORCID ID: https://orcid.org/0000-0002-0950-5027

\section{INTRODUCTION}

Silk has evolved closed to human beings from thousands of years, Silk ${ }^{1}$ based film forming solution make a film which is primary cover to protect wound from various contaminations also helps to heal in proliferative stage. In this novel drug delivery system spraying silk protein with polymeric solution on wound which form highly biocompatible1,4, biodegradable, and good mechanical strength film. The basic advantage of the film is to fulfil the skin requirement when wound happens and keep the wound moist, it also disinfects the wound.

Wound breaks the skin protective function. Wound healing 2 process of restoring the protective function and repairing the skin damage, which can be divided into three phases ${ }^{2}$. Inflammatory phase (Hemostasis / Inflammation), Proliferation phase and Maturation phase. Healing from the wound is a normal biological response to the injury that sets into motion a sequence of events. The ability to stimulate collagen synthesis ${ }^{3}$, Centella Asiatica has been used in skin care products for restoring skin firmness, elasticity and improving skin appearance.

\section{Silk protein specialty:}

Silk fibroin 4 is the natural protein derived from nonmammalian source (fig.1) having similar composition to mammalian dermal tissue and therefore behaves similar in its biological properties. This also makes silk fibroin free from any of the microbial contaminations detrimental to human health which present in collagen sourced from bovine tissues. The contact of silk fibroin with human plasma and cells do not involve any interaction with the inflammatory system ${ }^{4}$. The in-vitro study also shows keratinocytes, fibroblasts and other cells proliferate onto silk fibroin scaffolds. In-vivo study where in fibroin scaffolds are implanted in the mice skin for long term. There is not any inflammation, immune response, or fibrotic response. The amino acid sequence of Gla-Ala-Gla-Ala-Gla-Ser ${ }^{4}$ found fibroin, which are highly potential amino acid residues capable for re-epithelialization by active fibroblast movement. It has also got NAF (Natural Moisturizing factor) which is very similar to what body produce in human skin, thus it kept wound area moist to heal faster.

In this present study various formulations(F1-F8) of silkbased film forming spray solution designed, optimized, and evaluate for various parameters. Formulation plays major role in active healing of various wounds, Silk protein form scaffold for proliferation and Asiaticoside ${ }^{3}$ in maturation phase for active collagen synthesis. 


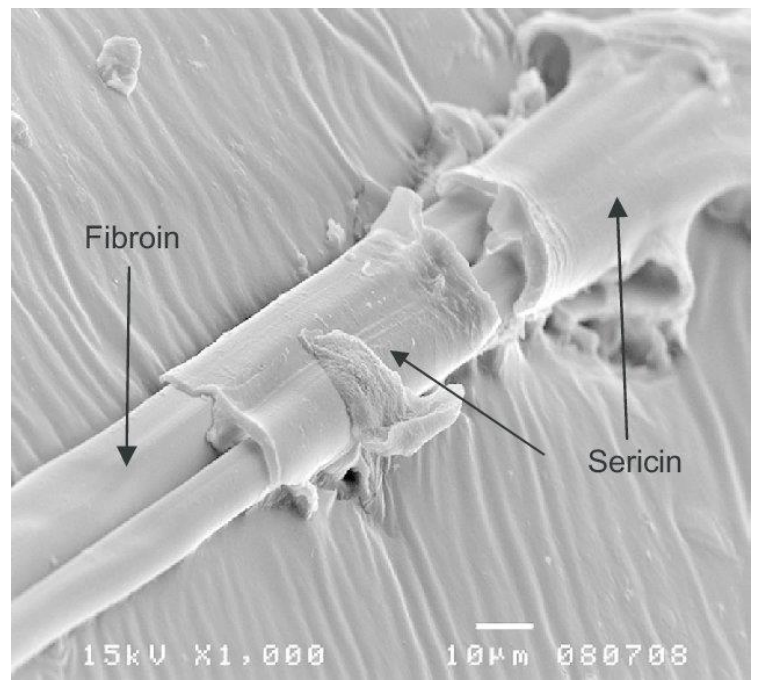

Figure 1: Protein components of Silk

\section{MATERIALS AND METHODS}

Centella Asiatica extract and Silk Protein (Fibroin) was received as gift sample from $\mathrm{M} / \mathrm{s}$. Healthline Pvt. Ltd. Polymers like PVP K30, PVA and Plasticizer PEG 400, PG, Glycerol was purchased from SD Fine-Chem Limited.

\section{Formulation \& development of spray solution:}

The solutions prepared by simple mixing using magnetic stirrer. $1 \mathrm{gm}$ of dried Centella Asiatica extract were first dispersed in $4 \mathrm{ml}$ of Propylene Glycol to make a uniform mixture. In another beaker $2 \mathrm{~g}$ of water-soluble Silk protein dispersed in $5 \mathrm{ml}$ of water. Mix both the suspension together, PVP K30 and PVA were dissolved in another beaker using ethanol and then mixed to the above suspension of Silk protein and Centella asiatica and stirred at $500 \mathrm{rpm}$ until a clear solution was obtained. PEG 400 and glycerol were then added to the solution and stirred until a homogeneous solution was obtained. The pale-yellow colored solution was obtained and stored in APF container at room temperature.

Table 1: Formulation of Silk-Based film forming spray solution

\begin{tabular}{|c|c|c|c|c|c|c|c|c|}
\hline \multirow[b]{2}{*}{ Formulations } & \multicolumn{8}{|c|}{ Ingredients (\%) } \\
\hline & $\begin{array}{c}\text { Centella } \\
\text { Asiatica } \\
\text { Extract }\end{array}$ & $\begin{array}{c}\text { Silk Protein } \\
\text { (Fibroin) }\end{array}$ & PG & Glycerol & $\begin{array}{l}\text { PEG } \\
400\end{array}$ & $\begin{array}{c}\text { FFP } \\
\text { (PVP K30 } \\
\text { +PVA 1:1) }\end{array}$ & Ethanol & $\begin{array}{c}\text { Purified } \\
\text { Water }\end{array}$ \\
\hline F1 & 1 & 2 & 4 & 2 & 4 & 4 & 40 & 43 \\
\hline F2 & 1 & 2 & 4 & 2 & 4 & 4 & 70 & 13 \\
\hline F3 & 1 & 2 & 4 & 2 & 4 & 6 & 40 & 41 \\
\hline F4 & 1 & 2 & 4 & 2 & 4 & 6 & 70 & 11 \\
\hline F5 & 1 & 2 & 4 & 2 & 8 & 4 & 40 & 39 \\
\hline F6 & 1 & 2 & 4 & 2 & 8 & 4 & 70 & 9 \\
\hline F7 & 1 & 2 & 4 & 2 & 8 & 6 & 40 & 37 \\
\hline F8 & 1 & 2 & 4 & 2 & 8 & 6 & 70 & 7 \\
\hline
\end{tabular}

\section{Optimization of Polymer, Plasticizers and Solvents:}

Quantitative selection of polymer, plasticizers and other solvent system done by using $2^{3}$ factorial designs.

\section{A. Optimization of Polymers}

PVP K-30 and PVA were selected for investigation of their capacity for spray formation. These film forming polymers were used at various concentrations (Table.1). The optimum polymer was selected based on the physicochemical properties and film formation behaviors. Both polymers are biodegradable and water soluble, PVP is miscible into PVA matrix and vice-versa due to strong $\mathrm{H}$ - bonding interactions between -OH groups of PVA.

\section{B. Optimization of solvent and plasticizers}

Solvent and Plasticizers ${ }^{7}$ having unique role in this formulation. Water is universal solvent along with that ethanol is used, it helps film dry quickly. Plasticizers such as Glycerol used in constant quantity and PEG 400:PG were used at concentrations of $1: 1$ and 2:1 ratio (Table.1).

\section{Selection of Containers:}

For storage of spray solution APF (Advance preservative free) screw-on spray container used for delivering the accurate quantity of medicaments from container. Spring loaded tip seal mechanism act as a physical barrier avoiding crystallization and contamination of product, clogging of nozzles can be avoided.

\section{Evaluation of spray solutions:}

Appearance: Appearance of the spray solutions was evaluated by visually such as Clarity, Adhesion and color

pH6: Using digital pH meter, the pH of the solution was calculated. The $\mathrm{pH}$ meter was calibrated before use with standard buffer solution at 4.0, 7.0 and 9.0.

Viscosity: Viscosity of spray solution was measured with a Brookfield Viscometer (model LV-DV-II, Helipatch-spindle type S-96, Germany).

Surface tension: Surface tension was measured with a Stalagmometer using Stalagmometry method (Drop Count Method), Surface tension( $\sigma$ ) was calculated by eq.

$$
\operatorname{Surface} \operatorname{tension}(\sigma)=\sigma 1 \times \rho 2 \mathrm{n} 1 / \rho 1 \mathrm{n} 2
$$

Where ' $\sigma 1$ ' is the Surface tension, ' $\rho 1$ ' is the Density and ' $n 1$ ' is a No. of Drops of reference fluid from A to B and ' $\sigma$ ' is the 
Surface tension, ' $\rho 2$ ' is the Density and 'n2 is a No. of Drops of topical film forming spray solution from $A$ to $B$.

Spray Angle: The sprays were actuated in horizontal direction onto a white paper mounted at $10 \mathrm{~cm}$ from the nozzle. Spray angle $(\theta)$ was calculated by eq. 2 .

$$
\text { Spray angle }(\theta)=\tan -1(1 / r)
$$

Where ' $\mathrm{l}$ ' is the distance between sprayer and paper, and ' $\mathrm{r}$ ' is radius of sprayed circle.

Volume of each spray - The volume of each spray was calculated using eq. 3 .

$$
(\mathrm{Vs})=(\mathrm{Wt}-\mathrm{Wo}) / \mathrm{D}
$$

Where Vs is the volume of sprayed, Wt is weight of solution after sprayed, Wo is the initial weight of solution in container, D is density. Average of five spray was calculated.

Evaporation Time/ Film Formation time: The evaporation time $^{5}$ or time to dry film completely was recorded. The appropriate amount of solution sprays on the glass surface and time required for getting the completely dry film was checked.

Stickiness of film: The stickiness of the film checked using cloths fibre, these fibres touched to film with applying less force and observed for that are retained by the film, the stickiness is rated high, medium and low.

Stability Studies: Stability studies ${ }^{5}$ of spray solutions were conducted for a duration of three months. The formulations were kept in lid tight APF container at the following conditions as per ICH guidelines: $30^{\circ} \mathrm{C} \pm 2^{\circ} \mathrm{C} / \mathbf{7 5} \pm \mathbf{5} \% \mathrm{RH}$. The samples were taken Initially 0 month and 3rd month and evaluated (Appearance, $\mathrm{pH}$ and Viscosity)

\section{RESULTS AND DISCUSSION}

The present research work attempted to develop and evaluate silk-based film forming spray for wound healing by selecting the best possible polymers like PVP K-30 and PVA along with efficient plasticizers like Glycerol, Propylene glycol and PEG400 used in a combination and solvents like water and ethanol to form protective cover on wound and heal wound effectively with less drying time, i.e. less than 5 min. The active constituents used in formulation are natural materials, Centella asiatica extract and Silk protein(fibroin).
Both materials having special role in formulation, Asiaticosides from Centella asiatica works in active collagen synthesis and Silk protein provides scaffolds active fibroblast movement and rapid proliferation.

The Appearance (fig.2) of the topical spray formulations were clear and slightly yellow or pale-yellow in color.

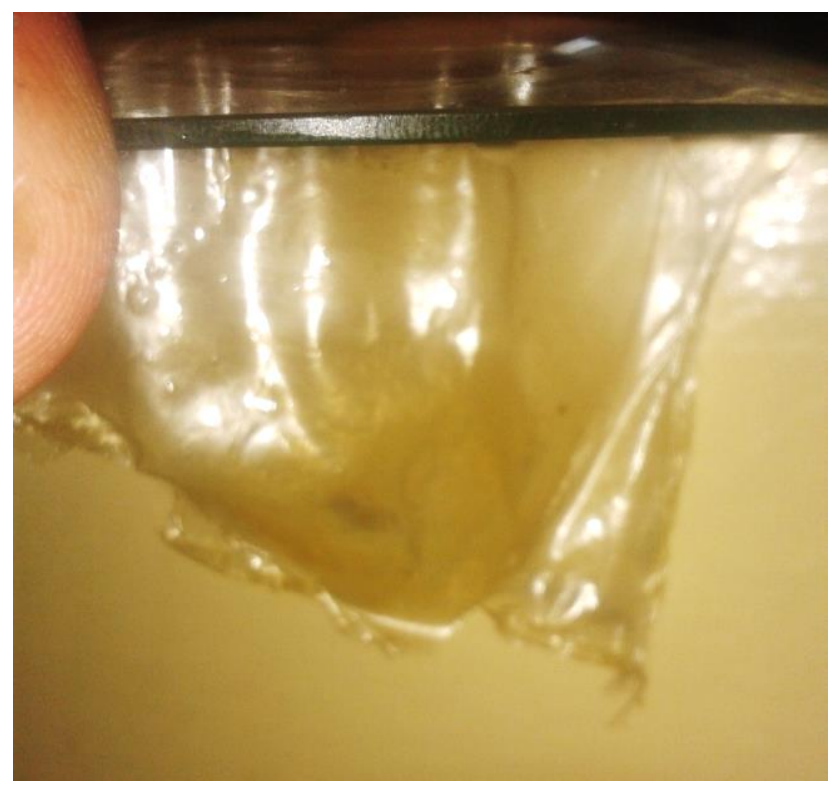

Figure 2: Appearance of Film

The $\mathrm{pH}$ of formulations (F1-F8) was in the range of 5.8 to 6.3 , which skin $\mathrm{pH}$ range 5.5 to 6.5 , so there is no need to adjust the $\mathrm{pH}$. The Viscosity of formulations (F1-F8) was in the range of 25-50 cps. The formulations were very low surface tension, indicating that the formulation could be spread well. The Surface tension of formulation was $20 \pm 5$ dyne $/ \mathrm{cm}$. Spray angle of solution in range of $50.5^{\circ} \pm 0.4^{\circ}$ to $55.5^{\circ} \pm 0.4^{\circ}$ The volume of each spray on an average was $130 \mu \mathrm{l} \pm 0.05 \mu$ l. The evaporation time or time required for the spray film to dry was $4 \mathrm{~min} 15 \mathrm{sec}$ for formulation(F8), which is less than $5 \mathrm{~min}$. The film was non-sticky or low stickiness of film to patient cloths.

\begin{tabular}{|c|c|c|c|c|}
\hline Formulations & Storage duration & Appearance & pH & Viscosity (cps) \\
\hline \multirow[t]{2}{*}{ F1 } & Initial & \multirow[t]{2}{*}{ Clear and Slightly Yellowish Solution } & 6.12 & 28 \\
\hline & 3 months & & 6.23 & 31 \\
\hline \multirow[t]{2}{*}{ F2 } & Initial & \multirow[t]{2}{*}{ Clear and Slightly Yellowish Solution } & 5.89 & 35 \\
\hline & 3 months & & 5.97 & 39 \\
\hline \multirow[t]{2}{*}{ F3 } & Initial & \multirow[t]{2}{*}{ Clear and Slightly Yellowish Solution } & 6.06 & 28 \\
\hline & 3 months & & 6.14 & 30 \\
\hline \multirow[t]{2}{*}{ F4 } & Initial & \multirow[t]{2}{*}{ Clear and Slightly Yellowish Solution } & 5.91 & 37 \\
\hline & 3 months & & 5.98 & 40 \\
\hline \multirow[t]{2}{*}{ F5 } & Initial & \multirow[t]{2}{*}{ Clear and Slightly Yellowish Solution } & 6.02 & 29 \\
\hline & 3 months & & 6.11 & 32 \\
\hline \multirow[t]{2}{*}{ F6 } & Initial & \multirow[t]{2}{*}{ Clear and Slightly Yellowish Solution } & 5.95 & 36 \\
\hline & 3 months & & 6.01 & 41 \\
\hline \multirow[t]{2}{*}{ F7 } & Initial & \multirow[t]{2}{*}{ Clear and Slightly Yellowish Solution } & 6.05 & 30 \\
\hline & 3 months & & 6.14 & 33 \\
\hline \multirow[t]{2}{*}{ F8 } & Initial & \multirow[t]{2}{*}{ Clear and Slightly Yellowish Solution } & 5.92 & 44 \\
\hline & 3 months & & 6.01 & 48 \\
\hline
\end{tabular}

Table 2: Stability results upon storage at $30^{\circ} \mathrm{C} \pm 2^{\circ} \mathrm{C} / 75 \pm 5 \% \mathrm{RH}$ 
No significant change in formulation properties were observed during the stability studies, it confirms that the formulations passed the stability test with aging at ambient and accelerated storage conditions.

\section{CONCLUSION}

Silk-based film forming spray for wound healing was successfully developed. Optimization of excipients and Physical evaluations showed acceptable results like

\section{ACKNOWLEDGEMENTS}

Thankful to M/s. Healthline Pvt Ltd and Aditya Bangalore Institute of Pharmacy Education and Research, Bangalore, Karnataka for providing research facilities. Special thanks to Mr. Bharat Tandon \& Dr. K.L.K Paranjothy.

\section{REFERENCES}

1. Altman G.H, Diaz F, Jakuba, C, Calabro T, Horan R.L, Chen J, Lu H, Richmond J, Kaplan D.L. Silk-based Biomaterials 2003; 24:401416; DOI: http://dx.doi.org/10.1016/s0142-9612(02)00353-8

2. Gonzalez A.C, Costa T.F, Andrade Z.A, Medrado A.R. Wound healing-A literature review, An Bras Dermatol. 2016 Sep-Oct; 91(5):614-620; DOI: http://dx.doi.org/10.1590/abd18064841.20164741.

3. K. J. Gohil, J. A. Patel and A. K. Gajjar, Pharmacological review on Centella asiatica: a potential herbal cure-all, Indian J. Pharm. Sci. appearance, $\mathrm{pH}$ and viscosity. The results showed that formulation(F8) had a high ability of spreading on wound surface with less drying time. Formulation can solidify on surface within 5 min. F8 showed high efficacy and pharmaceutically stable formulation for the treatment of wounds.

\section{CONFLICT OF INTEREST}

\section{No Conflict of interest}

2010; 72:546-556; DOI: http://dx.doi.org/10.4103/0250474X.78519

4. Pornanong Aramwit. Wound healing biomaterials, Functional Biomaterials 2016; 2:3-38; DOI https://dx.doi.org/10.1016/B978-1-78242-456-7.00001-5

5. Bakshi A., Bajaj A. et.al. A Novel Metered Dose Transdermal Spray Formulation for Oxybutynin, Indian J Pharm Sci. 2008; 70(6):733-739; $\quad$ DOI: $\quad$ http://dx.doi.org/10.4103/0250474X.49094

6. H. Lambers, S. Piessens, A. Bloem, H. Pronk and P. Finkel, Natural skin surface $\mathrm{pH}$ is on average below 5 , which is beneficial for its resident flora, Int. J. Cosmet. Sci. 2006; 28:359370; DOI: http://dx.doi.org/10.1111/j.1467-2494.2006.00344.x

7. Nesseem D.I, Eid S.F, El-Houseny S.S. Development of novel transdermal self-adhesive film for tenoxicam, an antiinflammatory drug. Life Sci. 2011; 89(13-14):430-438; DOI: http://dx.doi.org/10.1016/j.lfs.2011.06.026 